\title{
Representing northern peatland microtopography and hydrology within the Community Land Model
}

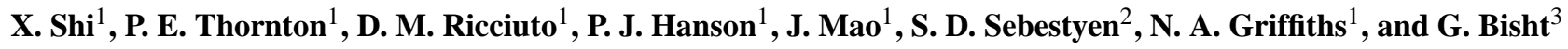 \\ ${ }^{1}$ Climate Change Science Institute and Environmental Sciences Division, Oak Ridge National Laboratory, Oak Ridge, \\ TN 37831, USA \\ ${ }^{2}$ Northern Research Station, USDA Forest Service, Grand Rapids, Minnesota 55744, USA \\ ${ }^{3}$ Climate and Ecosystem Sciences Division, Lawrence Berkeley National Laboratory, Berkeley, CA 94720, USA \\ Correspondence to: X. Shi (shix@ornl.gov) and P. E. Thornton (thorntonpe@ ornl.gov)
}

Received: 14 January 2015 - Published in Biogeosciences Discuss.: 20 February 2015

Revised: 25 August 2015 - Accepted: 14 September 2015 - Published: 12 November 2015

\begin{abstract}
Predictive understanding of northern peatland hydrology is a necessary precursor to understanding the fate of massive carbon stores in these systems under the influence of present and future climate change. Current models have begun to address microtopographic controls on peatland hydrology, but none have included a prognostic calculation of peatland water table depth for a vegetated wetland, independent of prescribed regional water tables. We introduce here a new configuration of the Community Land Model (CLM) which includes a fully prognostic water table calculation for a vegetated peatland. Our structural and process changes to CLM focus on modifications needed to represent the hydrologic cycle of bogs environment with perched water tables, as well as distinct hydrologic dynamics and vegetation communities of the raised hummock and sunken hollow microtopography characteristic of peatland bogs. The modified model was parameterized and independently evaluated against observations from an ombrotrophic raised-dome bog in northern Minnesota (S1-Bog), the site for the Spruce and Peatland Responses Under Climatic and Environmental Change experiment (SPRUCE). Simulated water table levels compared well with site-level observations. The new model predicts hydrologic changes in response to planned warming at the SPRUCE site. At present, standing water is commonly observed in bog hollows after large rainfall events during the growing season, but simulations suggest a sharp decrease in water table levels due to increased evapotranspiration under the most extreme warming level, nearly eliminating the occurrence of standing water in the growing season. Simulated soil energy balance was strongly influenced by reduced win-
\end{abstract}

ter snowpack under warming simulations, with the warming influence on soil temperature partly offset by the loss of insulating snowpack in early and late winter. The new model provides improved predictive capacity for seasonal hydrological dynamics in northern peatlands, and provides a useful foundation for investigation of northern peatland carbon exchange.

\section{Introduction}

Peatlands contain about $30 \%$ of global soil carbon, despite covering only $3 \%$ of the Earth's land surface (Gorham, 1991; Bridgham et al., 2006; Tarnocai, 2009). Northern peatlands play an important role in global carbon balance due to their capacity to store carbon and to exchange both $\mathrm{CO}_{2}$ and methane with the atmosphere. Carbon accumulated over thousands of years in these systems is projected to be vulnerable to climate warming (Wu et al., 2013). Manipulative experiments and process-resolving models are needed to make defensible projections of the net carbon balance of the northern peatlands in the face of a warming global environment.

In this paper we focus on hydrological dynamics of peatlands, as the water balance of peatlands plays a critical role in their carbon balance (Lafleur et al., 2003). Kettridge et al. (2013) showed the importance of peatland hydrology as a regulatory control on carbon dynamics and the future stability of peatland carbon stocks and regional water dynamics. Seasonal and interannual fluctuations in water table elevation can affect peatland net $\mathrm{CO}_{2}$ exchange through complex 
effects on soil processes (Mezbahuddin et al., 2014). Modeling by Grant et al. (2012) suggested that the productivity of wetlands is strongly affected by changes in water table level, and that the effects are complex and site-specific. Hydrologic dynamics can affect tree growth, and modify the density, size, and species distribution in peatlands (MacDonald and Yin, 1999; Robreck et al., 2009). Wu et al. (2013) showed that an increase of water table level by $15 \mathrm{~cm}$ could decrease net ecosystem production by up to $200 \%$ and switch peatlands from a net sink to a net source of carbon. As hydrology and biogeochemical cycling are tightly linked in peatlands (Waddington et al., 2001; Silvola et al., 1996; Dise et al., 2011), the accuracy of predicted peatland water table dynamics is likely to affect the accuracy of the predicted peatland carbon exchange. To the extent they are used to evaluate carbon cycle and climate system feedbacks, a reasonable requirement for land surface models operating within global climate models should therefore be that they make reliable predictions of peatland hydrology and hydrologic processes.

Peatland surfaces are often characterized by distinct micro-topography (hollows and hummocks) (Nungesser, 2003). The existence of hummock-hollow microtopography has important impacts on hydrological dynamics (Lindholm and Markkula, 1984; Verry et al., 2011b), nutrient availability (Chapin et al., 1979; Damman, 1978), plant species distribution and productivity (Andrus et al., 1983; Moore, 1989), and decomposition rates (Johnson and Damman, 1991). Many wetland ecosystem models drive biogeochemical simulations using observed water table depth as an input variable (St-Hilaire et al., 2010; Frolking et al., 2002; Hilbert et al., 2000). Even though such models include water table effects, the models have not simulated observed variation for hummock/hollow microtopography common to raised-dome bog peatlands. The absence of this important detail may limit the predictive capabilities of existing peatland models. Other ecohydrological models couple hydrology and carbon cycles in peatlands, but differ with respect to their hydrological schemes and the way they treat (or ignore) topography (Dimitrov et al., 2011). Some models, such as Biome-BGC (Bond-Lamberty et al., 2007), and Wetland-DNDC (Zhang et al., 2002) only simulate vertical soil water flow, neglecting lateral flow components (Dimitrov et al., 2011) within peatlands. Wania et al. (2010) describe a model of wetland hydrology and biogeochemistry (LPJ-WHyMe), but do not include consideration of microtopography or lateral flows. Others, such as BEPS (Chen et al., 2005, 2007) and InTEC v3.0 (Ju et al., 2006) include sophisticated ecohydrological and biogeochemical sub-models capable of simulating threedimensional hydrology (for large-scale topography) coupled to peatland carbon dynamics. Sonnentag et al. (2008) further adapted BEPS to model the effects of mesoscale (site level) topography on hydrology, and hence on $\mathrm{CO}_{2}$ exchange at Mer Bleue bog. Some advanced theoretical wetland models have included ecohydrological feedbacks for the patterning on peatlands (Frolking et al., 2010; Morris, 2013). Addition- ally, some cellular landscape models described by Swanson and Grigal (1988); Couwenberg and Joosten (2005); Eppinga et al. (2009) and Morris et al. (2013), dealing explicitly with fine-scale variability of peatland hydrology, have also been applied to explore peat development. The model presented by Bohn et al. (2013) includes fractional area representations for ridge and hollow in a wetland, but does not consider explicit lateral fluxes between these microtopographic units. To the best of our knowledge, only one ecosystem model currently includes representation of microtopographic variability (hummock-hollow topography) with lateral connection, that being the "ecosys" model (Grant et al., 2012). Ecosys tracks horizontal exchange between hummock and hollow elements, but its prediction of water table dynamics is constrained by specifying a regional water table at a fixed height and a fixed distance from the site of interest (mainly applied for a fen environment). Here we explore an extension of that approach, with lateral connections between hummock and hollow elements, and with a more mechanistic simulation of water table dynamics. Rather than specifying an external water table height, we predict bog water table dynamics in part as a function of bog geometry, including height of the bog's raised-dome center relative to a bog-scale drainage element (lagg), relative surface height differences between hummock and hollow, and fractional area contributions from hummocks and hollows. We implement this new capability within the Community Land Model (CLM), with the aim of expanding our simulations to large-scale bog simulations in subsequent studies.

The Community Land Model (CLM) (Oleson et al., 2013), the land component of the Community Earth System Model (CESM), couples water, carbon, nitrogen, and energy cycles together for the study of ecosystems. CLM does not currently represent vegetated peatlands (or vegetated wetlands of any type), nor does it represent lateral flow pathways common to surficial peats (Verry et al., 2011a, b). To realistically represent the hydrological dynamics of raiseddome bog microtopography in CLM, we incorporated structural and process changes characteristic of vegetated peatlands. CLM without and with our new modifications is hereafter referred to as CLM_Default and CLM_SPRUCE, respectively. A key objective for this effort was to produce an enhanced CLM_SPRUCE capable of being used for accurate simulations of high-carbon wetland hydrologic and carbon cycle responses for application to plausible future climate conditions. SPRUCE, the Spruce and Peatland Responses Under Climatic and Environmental Change experiment, is a 10-year warming by elevated $\mathrm{CO}_{2}$ manipulation of a high-carbon forested peatland in northern Minnesota designed to provide information on ecosystem changes under unique future warming and atmospheric conditions (http: //mnspruce.ornl.gov). The modified CLM model is parameterized from, and independently evaluated against, observations from pre-treatment data sets for the SPRUCE experiment and long-term peatland hydrology studies on the Mar- 
cell Experimental Forest (MEF). The model improvements reported here represent the first time that the isolated hydrologic cycle of an ombrotrophic bog, with its characteristic raised hummocks and sunken hollows, has been represented in the land surface component of an Earth system model. Hummock-hollow functionality within CLM_SPRUCE allows for the simulation of defensible estimates of peatland water table dynamics, necessary to predict dynamic $\mathrm{CO}_{2}$ and $\mathrm{CH}_{4}$ flux components for peatland carbon cycle predictions.

\section{Site description and measurement}

Our study focuses on an ombrotrophic bog (a raised-dome peat bog in which water and nutrient inputs originate from atmospheric sources). The specific study site is a high-carbon, boreal peatland, which is located approximately $40 \mathrm{~km}$ north of Grand Rapids, Minnesota, USA $\left(47^{\circ} 30.476^{\prime} \mathrm{N}\right.$; $93^{\circ} 27.162^{\prime} \mathrm{W}$ and $412 \mathrm{~m}$ above mean sea level). The site is designated the S1-Bog and is situated within the S1 watershed (Fig. 1). The S1-Bog and watershed have been part of a long-term research program of the USDA Forest Service Northern Research Station at the MEF for over 50 years (Verry et al., 2011c).

The S1-Bog is an 8.1 ha Picea-Sphagnum bog that was harvested in two successive strip cuts 5 years apart (1969 and 1974) (Sebestyen et al., 2011a). The bog surface has a hummock/hollow microtopography with a typical relief of 10 to $30 \mathrm{~cm}$ between the tops of the hummocks and the bottoms of the hollows (Nichols, 1998). The elevation of the hollows is fairly consistent throughout the S1-Bog, but increases along a gentle slope to the highest point of the raised-dome near the center of the bog (Verry, 1984; Richardson et al., 2010). The vegetation, climate, hydrology, long-term monitoring, and post-European settlement site history are described in Sebestyen et al. (2011a). Briefly, vegetation within the S1Bog is dominated by the tree species Picea mariana (Mill.) B.S.P and Larix laricina (Du Roi) K. Koch, a variety of ericaceous shrubs, and Sphagnum sp. moss. Mean annual air temperature is $3.4^{\circ} \mathrm{C}$, and the average annual precipitation is $780 \mathrm{~mm}$ (Verry and Jansenns, 2011), with $75 \%$ of the precipitation occurring in the snow-free period from mid-April to early November. Mean annual air temperatures have increased about $0.4{ }^{\circ} \mathrm{C}$ per decade over the last 40 years.

Peatlands at the MEF formed as ice-block depressions infilled over the past 11000 years (Verry and Jansenns, 2011). The peatlands are surrounded by gently sloping upland mineral soils that drain toward the peatland. The peat deposit in the S1-Bog is generally 2 to $4 \mathrm{~m}$ deep with maximum depths of $11 \mathrm{~m}$ (Parsekian et al., 2012). In a typical year, the peatland water table fluctuates within the top $30 \mathrm{~cm}$ of peat (Sebestyen et al., 2011b), which corresponds to peats that are least decomposed and have the highest hydraulic conductivities (Verry et al., 2011a). As such, water flows laterally through these highly conductive peats when water ta-

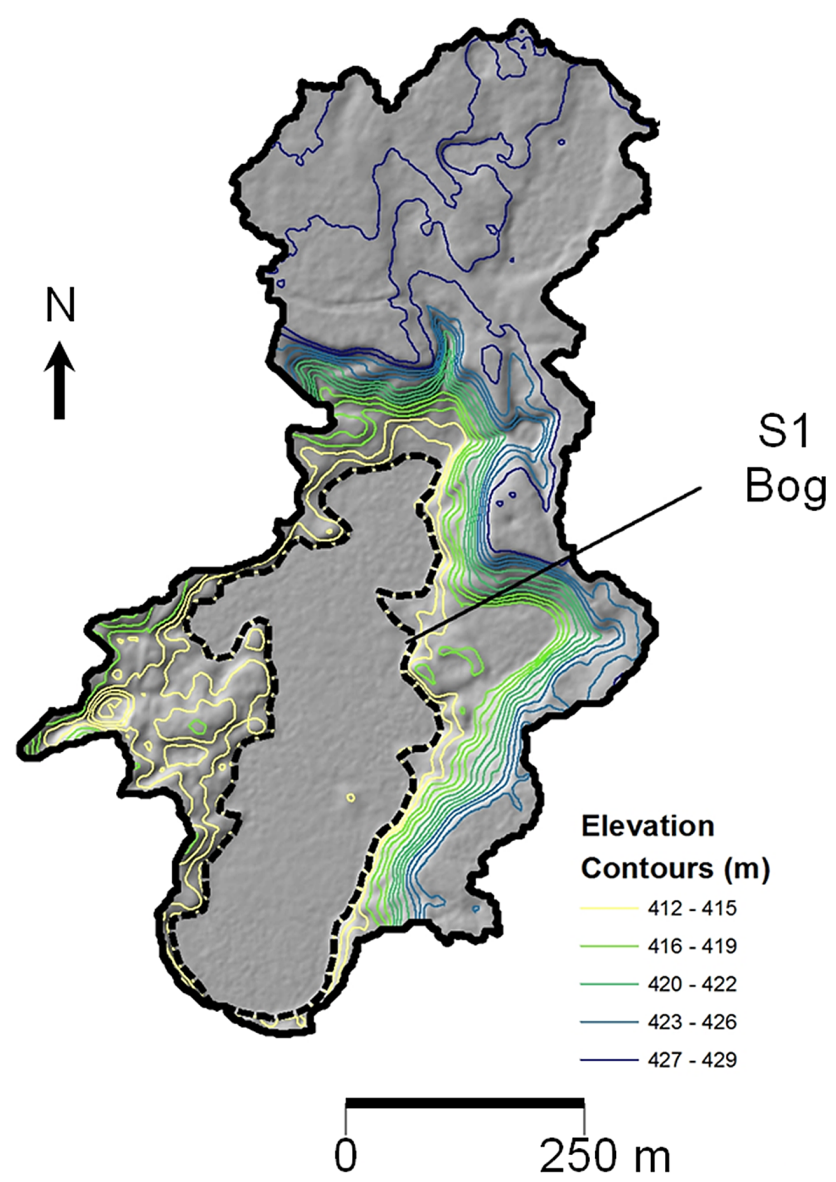

Figure 1. The topography of the S1 Watershed on the Marcell Experimental Forest, which contains the S1-Bog peatland.

bles are near the peat surface and the peatland water table is above the elevation of the peatland outlet. The peatland has two hydrologically and vegetationally distinct zones: the bog and the surrounding lag zone (Verry et al., 2011b). The central raised-dome bog radially drains to the peatland perimeter (the lagg zone) when water tables are near the peat surface (Fig. 2). Water flows into the peatland lagg from both the upland and bog soils and the lagg coalesces into an outlet stream (Fig. 2). Streamflow is intermittent, with flow occurring during snowmelt and after large rainfall events. Some water does exit the peatland through lateral subsurface flow through a sand berm that forms the southern boundary of the peatland, and through the bottom of the ancient lake bed. The broadly domed surface of the bog is characterized by a microtopography of raised hummocks and sunken hollows. The mean height of the bog surface above the level of the lagg is estimated as $0.7 \mathrm{~m}$ to the hummock surfaces, and $0.4 \mathrm{~m}$ to the hollow surfaces, which is typical of raised-dome bog structure in general.

Evapotranspiration (ET) is $\sim 65 \%$ of annual precipitation in peatlands at the MEF (Brooks et al., 2011). As a part of SPRUCE pretreatment measurement protocols, wa- 


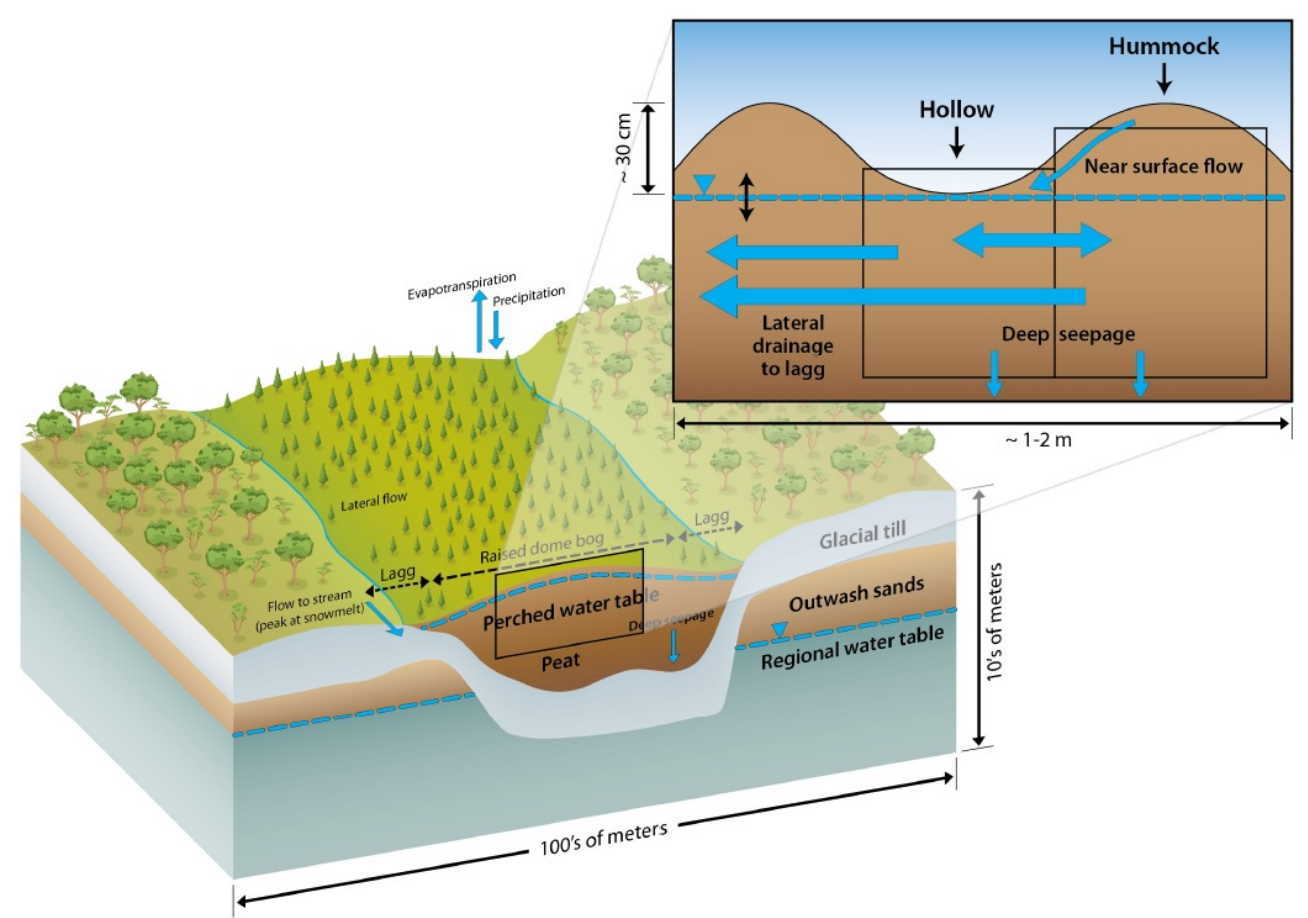

Figure 2. Conceptualization of hummock and hollow microtopography within raised-dome bog ecosystem. The broad view shows the bog water table perched above regional water table, due to hydrologic isolation of the bog by underlying glacial till. The inset shows an idealized cross-section view of microtopography, with model representation of hummock and hollow columns (black outlines) and water fluxes (solid blue arrows) between columns and from columns to the bog-scale drainage feature (lagg). Bog water table is shown as dashed blue line.

ter table levels have been measured every $30 \mathrm{~min}$ at the meteorological stations (EM1 and EM2) that are approximately $3 \mathrm{~m}$ apart in the S1-Bog (data and metadata are available at ftp://mnspruce.ornl.gov/SPRUCE_EM_DATA_ 2010_2011/). Water levels were recorded from TruTrack WT-VO water level sensors $( \pm \sim 2 \mathrm{~mm}$ resolution, http:// www.trutrack.com/WT-VO.html) using Campbell Scientific CR1000 dataloggers. The two water level sensors were placed in hollows at EM1 and EM2. Water table levels have been recorded since 2011 with the exception of periods of frozen peat when the sensors are nonfunctional. In this study, water table height is referenced to zero at the hollow surface. Positive values indicate standing water in the hollows, and negative values indicate that water table is below hollow surfaces.

While measurements of ET are not available for the S1Bog, annual ET estimated on the basis of water budget measurements is available for a 21-year period of record (19791999) at the nearby S2-Bog (Nichols and Verry, 2001). The physical setting, vegetation types and water table dynamics of the S1 and S2 Bogs are similar, except the S2-Bog did not undergo the strip cuts.

\section{Model description and experiment design}

\subsection{Model description}

We used the Community Land Model version 4.5 (CLM4.5) as the starting point for our model development and evaluation. The new features of CLM4.5 (Oleson et al., 2013) compared to its predecessor CLM4 include improved canopy processes, soil hydrology updates, a new lake model, a vertically resolved soil biogeochemistry scheme (Koven et al., 2013), a new fire model, a methane production, oxidation, and emissions model (Riley et al., 2011) and an optional runoff generation scheme (Li et al., 2011). Hydrology improvements in CLM4.5 include introduction of an ice impedance function, surface water and other corrections that increase the consistency between soil water saturated state and water table position, allowing for the maintenance of a perched water table above permafrost layers (Swenson et al., 2012).

The default CLM4.5 hydrology parameterizes interception, throughfall, canopy drip, snow accumulation and melt, water transfer between snow layers, infiltration, evaporation, surface runoff, sub-surface drainage, vertical transport through the vadose zone, and groundwater discharge and recharge (Fig. 7.1 in Oleson et al., 2013). CLM4.5 also includes hydrologic and thermal properties for organic-rich peat in addition to mineral soils. CLM4.5 does not include in- 
teractions between horizontally variable soil columns, so no lateral flows are represented. The default CLM4.5 parameterization for subsurface drainage produces an unrealistically deep water table relative to observations in wetlands (Oleson et al., 2008). For this study we use the thermal and hydraulic properties of peat as defined globally in CLM 4.5 (Lawrence and Slater, 2007) with the exception of the maximum subsurface drainage rate, which is calibrated for the site $\left(q_{\text {drai, } 0}\right.$, see next section).

\subsection{New formulation for raised-dome bog hydrology}

Microtopography is simulated in CLM_SPRUCE by two interconnected soil profiles representing the hummock and hollow areas, with the hollow surface set $0.3 \mathrm{~m}$ lower than that of the hummock, and with otherwise identical physical properties with depth. The bog area is assumed to be $75 \%$ hummock and $25 \%$ hollow, an approximation based on site measurements. We added several new structure and process representations to CLM4.5 to improve correspondence with observed features of the S1-Bog (Fig. 2, inset). Modifications include (1) reformulation of the subsurface drainage term to represent horizontal subsurface flow from the bog to the lagg which then drains to the outlet stream; (2) introduction of a two-column structure to represent hummock and hollow microtopography; (3) addition of lateral transport to represent saturated equilibration between the hummock and hollow columns; (4) introduction of surface runoff from hummocks to hollows; and (5) drainage of surface water in the hollows to the lagg. Our intent with this particular set of modifications was to capture the physical and hydrological processes that distinguish an ombrotrophic bog from the more general soil hydrology representation in the original model.

The original formulation for subsurface runoff uses a TOPMODEL-based approach for surface and subsurface runoff (Niu et al., 2005). Subsurface drainage rate $q_{\text {drai }}$ exponentially decays with water table depth:

$q_{\text {drai }}=q_{\text {drai }, 0} \exp \left(-f_{\text {drai }}\left(z_{\mathrm{W}}\right)\right)$.

Here, $q_{\text {drai,0 }}$ is the maximum subsurface drainage rate $\left(\mathrm{Kg} \mathrm{m}^{-2} \mathrm{~s}^{-1}\right)$, which occurs when the water table is at the surface. $f_{\text {drai }}$ is the exponential decay factor $\left(\mathrm{m}^{-1}\right)$, and $z_{\mathrm{w}}$ is the depth of the water table below the surface $(\mathrm{m})$. For our new model we use the default global value $f_{\text {drai }}=2.5 \mathrm{~m}^{-1}$ from CLM4.5 (Oleson et al., 2013), but we modify Eq. (1) such that the subsurface drainage term becomes zero when the water table depth drops to the local depth of the lagg $z_{\text {lagg }}$ $(0.4 \mathrm{~m}$ relative to the hollow surface and $0.7 \mathrm{~m}$ relative to the hummock surface as a mean value for the S1-Bog):

$$
\begin{aligned}
& q_{\text {drai }}=q_{\text {drai }, 0}\left(\exp \left(-f_{\text {drai }}\left(z_{\mathrm{W}}\right)\right)-\exp \left(-f_{\text {drai }}\left(z_{\text {lagg }}\right)\right)\right), \\
& z_{\mathrm{W}}<z_{\text {lagg }} \\
& q_{\text {drai }}=0, \text { otherwise. }
\end{aligned}
$$

This model parameterization represents an assumed barrier to lateral and vertical drainage imposed by the glacial till layer when the water table is below the level of the lagg. At the S1-Bog, there is an observed small but persistent "deep seepage" term representing vertical subsurface drainage from the perched bog water table (included in Fig. 2, but set to zero for simulations here, due to a lack of adequate data for parameterization). For this study, the maximum subsurface drainage rate $q_{\text {drai, } 0}$ is calibrated against site water table observations.

For modification (3), the simulated lateral transport of water, $q_{\text {lat, aqu }}\left(\mathrm{mm} \mathrm{s}^{-1}\right)$, is a function of the difference in simulated water table level between the hummock and hollow columns, the specific yield of the soil layer in question, the average hydraulic conductivity and the average horizontal distance between columns:

$q_{\text {lat }, \mathrm{aqu}}=\frac{\left(\frac{k_{\mathrm{hum}}+k_{\mathrm{hol}}}{2}\left(z_{\mathrm{w}, \mathrm{hum}}-z_{\mathrm{w}, \mathrm{hol}}^{*}\right)\right)}{\Delta x}$

$k_{\text {hum }}\left(\mathrm{mm} \mathrm{s}^{-1}\right)$ is the weighted mean saturated hydraulic conductivity of the hummock layers containing the aquifer, and $k_{\text {hol }}\left(\mathrm{mm} \mathrm{s}^{-1}\right)$ is the weighted mean saturated hydraulic conductivity hollow layers containing the aquifer. We used CLM4.5 default peatland saturated hydraulic conductivity values, which decrease as a function of depth (Oleson et al., 2013) and fall in the observed range for bogs in the region (Verry et al., 2011a). $\Delta x$ is the horizontal separation between the hummock and hollow columns, which is assumed to be $1 \mathrm{~m}$. Variables $z_{\mathrm{w} \text {,hum }}$ and $z_{\mathrm{w} \text {,hol }}^{*}$ represent the hummock and adjusted hollow water table depths (meters) relative to the hollow surface. The adjusted hollow water table depth $z_{\mathrm{w}, \text { hol }}^{*}$ reflects a reduction in water table depth by the height of surface water that is present on the hollow surface. To transport water laterally between hummock and hollow, we first use CLM's calculation of specific yield for the soil layer containing the water table and determine the difference in water table height resulting from the lateral flux. If the magnitude of the lateral flux is larger than the capacity of that layer, the water table may move into higher or lower layers using the same relationship between specific yield of those layers and water table height. Transport from hollow surface water into the hummock soil column may also occur.

Modification (4) involves directing the surface runoff term calculated on the hummock as an input term to the hollow surface. Because of the large infiltration capacity of peat, this term is most relevant when the upper peat layers of the hummock are frozen.

The implementation of surface water storage and runoff in CLM 4.5 considers microtopography across an entire grid cell rather than within the wetland portion of a grid cell, and does not account for the effects of peatland microtopography (Oleson et al., 2013). Here we assume that the hollows are interconnected, and the surface water runoff from the hollows is determined by the slope of the raised-dome bog and the surface water height. Therefore for modification (5), we replace the formulation of surface water runoff using the for- 
mulation for wetland flow by Kadlec and Knight (2009) that includes a vertical stem density gradient and a bottom slope, modified by Kazezy1lmaz-Alhan et al. (2007):

$q_{\mathrm{h} 2 \mathrm{o}, \mathrm{sfc}}=r_{\mathrm{h} 2 \mathrm{osfc}} z_{\mathrm{h} 2 \mathrm{osfc}}^{2}$.

Here, $q_{\mathrm{h} 2 \mathrm{o}, \mathrm{sfc}}$ is the surface water drainage rate $\left(\mathrm{kg} \mathrm{m}^{-2} \mathrm{~s}^{-1}\right)$ and $z_{\mathrm{h} 2 o s f c}$ is the surface water height in the hollow (m). The parameter $r_{\mathrm{h} 2 o s f c}$ is an aggregated coefficient that includes both vegetation-induced friction and the bottom slope of the hollows in the raised-dome bog. This parameter is calibrated against observations to improve model performance at the S1-Bog (results in Table 1).

Our current implementation of CLM_SPRUCE does not include a unique biophysical parameterization for Sphagnum moss, which is a recognized shortcoming. Other efforts are underway to quantify the unique hydraulic and physiological properties of moss, including field studies in the S1-Bog and laboratory studies based on S1-Bog samples. Introduction of lateral connectivity and bog geometry and microtopography are first-order steps toward improved representation of peatland hydrology. We intend to include new parameterizations emerging from observational and experimental efforts in subsequent work with CLM_SPRUCE.

\subsection{Simulation experiment setup}

Picea, Larix, and shrubs are represented by the corresponding CLM plant functional types. Because Sphagnum moss physiology is not represented in CLM, we use the C3 grass plant functional type to represent both sedges and Sphagnum moss. Both hummock and hollows include the same vegetation distributions. Simulations were conducted using CLM_Default and CLM_SPRUCE with prescribed vegetation canopy phenology. To capture site evapotranspiration from vegetation, the maximum leaf area indices were based on site observations. Several model parameters were set to match site observations, including leaf $\mathrm{C}: \mathrm{N}$ ratios, rooting depth profiles and specific leaf area (Table 1). Since this study focuses on the site hydrology, biogeochemistry is turned off in the model to avoid computationally costly carbon pool spinups, and carbon fluxes have not been tracked for these annual hydrologic simulations.

Half-hour SPRUCE environmental driver data are being collected and have been available since 2011, but a longer data sequence was needed for model simulations. The model is driven by 35-year (1979-2013) environmental reanalysis data from NCEP2 (Kanamitsu et al., 2002) including temperature, precipitation, specific humidity, solar radiation, wind speed, pressure and longwave radiation at a $6 \mathrm{~h}$ time step and extracted for the gridcell containing the S1-Bog. NCEP precipitation was rescaled using daily precipitation data from a recording rain gage in the nearby South Meteorological Station at the MEF (Sebestyen et al., 2011a).

The 10-year long SPRUCE climate change field experiment at the S1-Bog will consist of combined manipulations of temperature (various differentials up to $9 \mathrm{~K}$ above ambient) and $\mathrm{CO}_{2}$ concentration (ambient and 800-900 ppm). To investigate how the bog water table levels in hummock/hollow microtopography may respond to different warming scenarios, we performed eight simulations from the same starting point in year 2000, designed to reflect the warming treatments being implemented in the field. The model simulations include a control simulation (CTL), and six simulations with increasing air temperature $(+3,+6$, and $+9 \mathrm{~K}$ above ambient, respectively) under two humidity conditions. Three of these six simulations used the same specific humidity $(Q)$ as CTL, which will be referred to here as "warming and constant $Q$ ". The other three simulations used the same relative humidity (RH) as CTL, (and hence, due to warmer air temperatures, higher $Q$ ), denoted here as "warming and constant RH". The final simulation increased air temperature by $+9 \mathrm{~K}$ and specific humidity by $30 \%$, which is lower than the constant RH scenario. This final humidity setting is based on the projection of CESM under RCP8.5 scenario at the end of 21st century (Moore et al., 2013). We note that the warming and constant $Q$ scenario most closely represents the planned experimental manipulation at SPRUCE, since there will be no water vapor additions. The treatments for the SPRUCE field experiment will include belowground soil warming achieved with vertical heating elements (Hanson et al., 2011). The purpose of the belowground heating is to compensate for subsurface heat loss around the edges of the aboveground enclosures. Since CLM_SPRUCE does not account for lateral heat flow, the planned SPRUCE active belowground heat manipulations are not included in the current simulations. To estimate incoming longwave radiation under the warming scenarios, we use clear-sky assumptions about atmospheric temperature, humidity, and emissivity (Idso et al., 1981).

Parameter calibrations for $q_{\mathrm{drai}}$ and $r_{\mathrm{h} 20 \mathrm{osfc}}$ are performed jointly using a genetic algorithm (Thomas and Yao, 2000) requiring 1000 simulations, and optimizes the model against the daily observed water table level from 2011 and 2012. Observations from the year 2013 are used for evaluation. The calibrated model with our new modifications is then compared with the observations and used to predict future scenarios.

As an independent evaluation of the modeled relationship between annual evapotranspiration (ET) and annual air temperature $(T)$, we compared model results for the 21-year period 1979-1999 with observations of ET from the nearby S2Bog. We further explored the ET vs. $T$ relationship over the range of warming treatments, in an effort to place some confidence bounds on our model findings regarding changes in bog hydrology under experimental warming. 
Table 1. Model parameter values which were modified from default values to reflect site-level measurements or optimized parameters. All measured parameters were used to define vegetation physiology, and were applied separately to each of the dominant species or plant functional types (PFTs) included in the simulations. Optimized parameters were generated at the level of the soil column. For the case of the vegetation physiological parameter (mp), this means that the same value was applied for all vegetation types. Optimized hydrologic parameters were applied to both hummock and hollow columns. ENFB = evergreen needleleaf forest - boreal; DNFB $=$ deciduous needleleaf forest - boreal. Units: dim $=$ dimensionless.

\begin{tabular}{|c|c|c|c|c|c|c|}
\hline Parameter & Description & Units & Black spruce (ENFB) & Larch (DNFB) & Shrub & Grass \\
\hline $\begin{array}{l}\text { Measured parameter } \\
\text { pct_pft }\end{array}$ & Percentage of PFT in gridcell & $\%$ & 35 & 15 & 20 & 30 \\
\hline leafen & Leaf carbon : nitrogen ratio & $\mathrm{gC} / \mathrm{gN}$ & 67 & 24 & 40 & 38 \\
\hline $\begin{array}{l}\text { SLAtop } \\
\text { Optimized parameter }\end{array}$ & Specific leaf area at canopy top & $\mathrm{m}^{2} / \mathrm{gC}$ & $\begin{array}{l}0.0075 \\
\text { Column-level }\end{array}$ & 0.022 & 0.012 & 0.03 \\
\hline $\mathrm{mp}$ & Ball-Berry stomatal conductance slope & $\operatorname{dim}$ & 6.4 & & & \\
\hline$r_{\mathrm{h} 2 \mathrm{osfc}}$ & Surface water runoff & $\mathrm{kg} \mathrm{m}^{-4} \mathrm{~s}^{-1}$ & $8.40 \times 10^{-08}$ & & & \\
\hline$q_{\mathrm{drai}, 0}$ & Maximum subsurface drainage rate & $\mathrm{kg} \mathrm{m}^{-2} \mathrm{~s}^{-1}$ & $9.20 \times 10^{-06}$ & & & \\
\hline
\end{tabular}

\section{Results}

\subsection{Simulated water table level}

Simulations with (CLM_SPRUCE) and without (CLM_Default) our new hydrological treatment are used to test the influence of new model representations of hydrological processes at the microtopographic level of peatland hummocks and hollows. CLM_Default produces a water table depth of 3-4 m (Fig. 3a), which can be considered representative of the regional water table in the upland and below the bog (Verry et al., 2011b), but is not realistic of the perched water table in the bog itself. Reformulating lateral drainage flow from the bog to the lagg as a function of the height difference between the simulated bog water table and the lagg outlet, CLM_SPRUCE simulates a water table depth of $<1 \mathrm{~m}$ (a perched water table, Fig. 3a). CLM_SPRUCE simulates independent water tables for the hummock and hollow bog elements, but by parameterizing near-surface and sub-surface hydraulic connectivity between hummock and hollow, the water tables in these two elements track each other on short timescales (Fig. 3b). The small differences between hummock and hollow water tables occur during large precipitation events. CLM_SPRUCE simulates standing water in the hollow during snowmelt and after large precipitation events, with drying of the hollows due to drainage to the lagg and evapotranspiration. In the summer of 2012 a prolonged period of low precipitation resulted in a simulated water table decline to approximately $30 \mathrm{~cm}$ below the surface of the hollow. Mean annual water budget predicted by the model has ET as $57.48 \%$ of annual precipitation, in reasonable agreement with the observed value of $65 \%$ (Fig. 8).
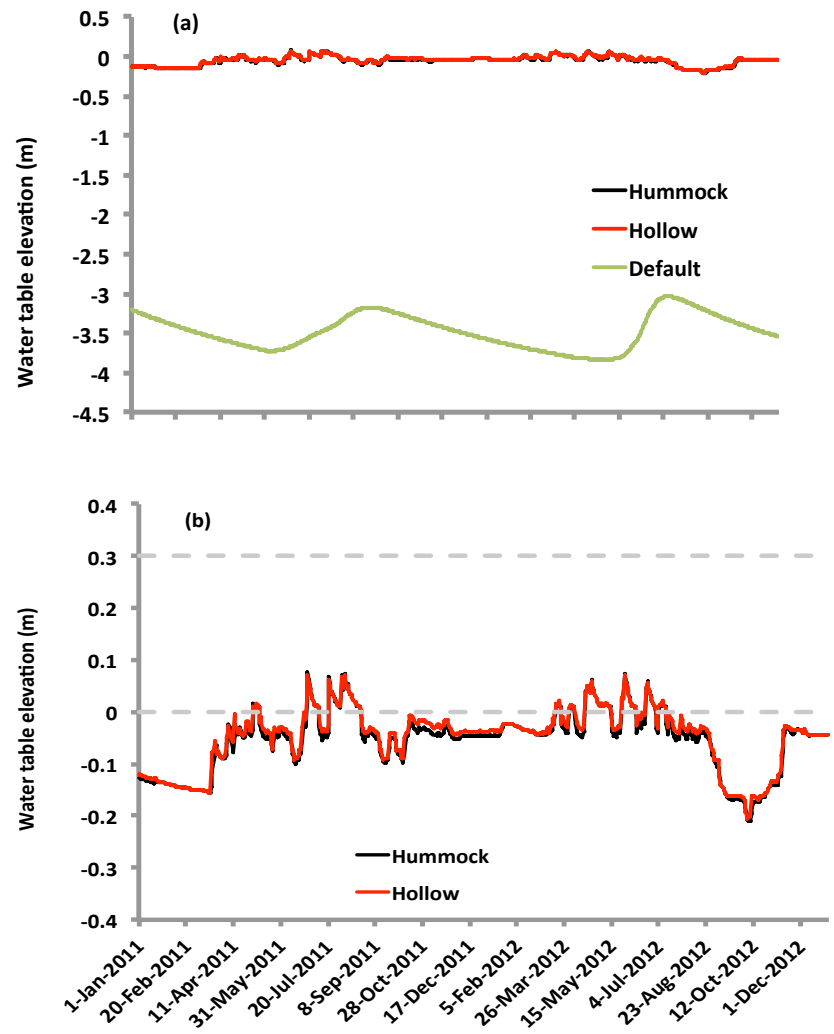

Figure 3. CLM_Default and CLM_SPRUCE simulated hummock and hollow water table levels (a), and CLM_SPRUCE predicted water table dynamics (b) for years 2011 and 2012. Dashed lines show the height of the surface of the hummock $(0.3 \mathrm{~m})$ and hollow $(0 \mathrm{~m})$.

Time series observations of water table height from two sensors (EM1 and EM2) located within the S1-Bog and separated by $\sim 3 \mathrm{~m}$ were available for parts of calendar years 2011, 2012, and 2013. The water table depth data from these sensors are in good agreement with water table data from 10 additional sensors distributed across the S1-Bog in 


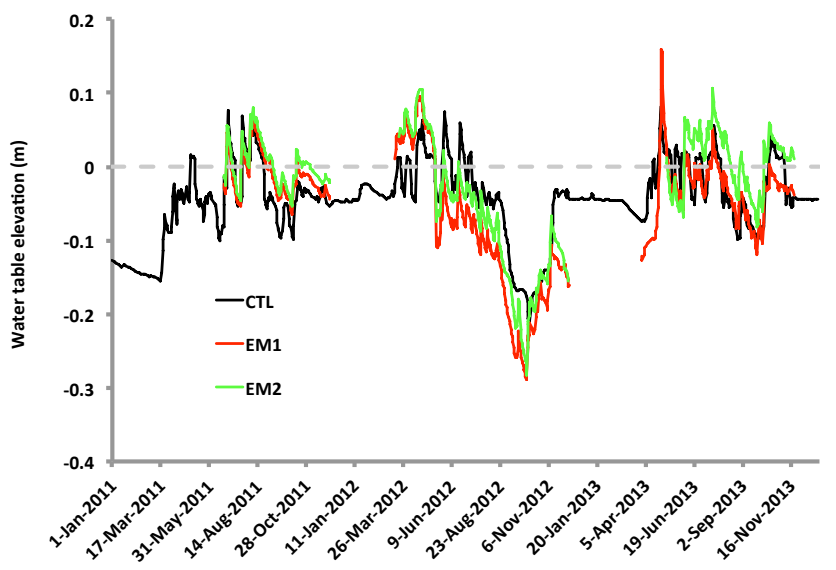

Figure 4. The comparison of CLM_SPRUCE simulated (CTL) and observed water table levels (EM1 and EM2) for hummocks for the years 2011 to 2013. Zero line indicates the surface of the hollow. For clarity, model results are shown only for the simulated hummock: simulated water table heights are nearly identical for hummock and hollow (Data are missing from EM1 and EM2 during winter when the bog surface is frozen and the water table sensors are not collecting data).

2014. Data from 2011 and 2012 were used to parameterize the new lateral drainage terms in CLM_SPRUCE (Table 1), with observations from 2013 used for evaluation. The model CLM_SPRUCE captures the timing and magnitude of observed water table dynamics in 2011 and 2012, with some periods of underestimation in 2011 and overestimation in 2012, but no clear indication of a consistent prediction bias. Water table height predictions for the evaluation year, 2013, are in good agreement with observations $\left(R^{2}=0.51\right)$ for both timing and magnitude (Fig. 4).

\subsection{Simulated hydrologic response to climate warming}

\subsubsection{Influence of warming and humidity changes on simulated water table heights}

Simulated warming of the bog through an imposed increase in near-surface air temperature results in model prediction of drying and a deeper water table (Fig. 5). The magnitude of warming effects on water table height is influenced strongly by assumptions regarding changes in humidity. For the case where absolute humidity $\left(Q, \mathrm{~kg} \mathrm{H}_{2} \mathrm{O} \mathrm{kg}\right.$ dry air $\left.^{-1}\right)$ is unchanged (in comparison to control), all warming treatments $(+3,+6$, and $+9 \mathrm{~K})$ cause a deepening of water table level (Table 2), with a deepening of $\sim 15 \mathrm{~cm}$ year-round for the $+9 \mathrm{~K}$ scenario (Fig. 5a). Under this scenario the system shifts from frequent periods of standing water in the hollows in spring and following large precipitation events (CTL), to an almost complete absence of standing water periods $(+9 \mathrm{~K})$. The mean state of the water table in summer months for the $+9 \mathrm{~K}$ case with constant $Q$ is lower than the deepest water table exhibited in the control scenario under dry conditions in the summer of 2012. Under the alternative assumption for humidity changes, in which relative humidity is maintained as in the control (requiring progressive increases in absolute humidity under $+3,+6$, and $+9 \mathrm{~K}$ warming scenarios), water table height is lowered only on average by $\sim 5 \mathrm{~cm}$, with some evidence of slower recovery from deeper water table at the end of the summer 2012 dry period (Fig. 5b). The planned experimental manipulations for the SPRUCE chambers will consist of increased air temperature but no additions of water vapor (due to cost constraint), so the eventual experimental conditions will be close to the assumptions shown here for the constant $Q$ case (Fig. 5a). Earth system model predictions for future climate change actually fall somewhere between the two end-point cases illustrated in Figure 6. Based on results from the CESM for a future radiative forcing of $8.5 \mathrm{~W} \mathrm{~m}^{-2}$, which generates a regional near-surface air temperature increase of almost $9 \mathrm{~K}$ by year 2100 and so seems a reasonable candidate global simulation for this purpose, the regional specific humidity increased by $30 \%$, corresponding to a $14 \%$ decrease in relative humidity. Evaluating CLM_SPRUCE results when forced with this example climate model projection, we find that the projected response for the end of the century falls between the two endpoint simulations already shown, and is generally closer to our constant $Q$ case than to our constant RH case (Fig. 6).

\subsubsection{Influence of warming on simulated evapotranspiration}

Since the constant $Q$ scenarios most closely follow the planned experimental treatment, we explore evapotranspiration (ET) and its components response to the warming with only these simulations. ET in CLM_SPRUCE is the sum of three components: transpiration (TR), canopy evaporation $\left(E_{\mathrm{c}}\right)$ and soil evaporation $\left(E_{\mathrm{s}}\right)$. These modeled water budget terms include tree, shrub, and herbaceous vegetation. ET and its components increase with air temperature for both hummock and hollow under air temperature increased by $+3,+6$ and $+9 \mathrm{~K}$ warming scenarios, whose magnitudes scale with the increases of temperature (Table 2). ET is predicted to increase by $53.24,76.7$ and $87.61 \%$ for the hummock under the three warming scenarios (by $61,25,91.5$ and $116.35 \%$ for hollow), respectively. Soil evaporation shows the biggest percentage increase with warming, especially soil evaporation from the hollows. For example, evaporation from hollows increased by about 132,198 , and $256 \%$ when the air temperature increased by $+3,+6$ and $+9 \mathrm{~K}$, respectively. Canopy evaporation shows the smallest changes with the three different increases of air temperature (Table 2). The seasonal pattern of transpiration shows that warming causes higher simulated transpiration throughout the growing season, with the largest absolute increases in mid-summer (Fig. 7, top row). Three-year averaged time evolution of canopy evaporation demonstrates that $E_{\mathrm{c}}$ is little affected by warming in these simulations, indicating that temperatures and incident radia- 
Table 2. The relative changes (as compared to the control) in annual ET and its components, and water table levels (WT) (averaged over the period of 2011 to 2013) in the hummock (Hum) and hollow (Hol) under different warming scenarios with constant $Q$ experiments (TR, $E_{\mathrm{c}}$ and $E_{\mathrm{S}}$ are canopy transpiration, canopy evaporation and soil evaporation, respectively).

\begin{tabular}{rrrrrrrrrrr}
\hline \multirow{2}{*}{$\begin{array}{r}\text { Warming } \\
\text { scenario }\end{array}$} & \multicolumn{2}{c}{ Effects on ET (\%) } & \multicolumn{2}{c}{ Effects on TR $(\%)$} & \multicolumn{2}{c}{ Effects on $E_{\mathrm{c}}(\%)$} & \multicolumn{2}{c}{ Effects on $E_{\mathrm{S}}(\%)$} & \multicolumn{2}{c}{ Effects on WT (cm) } \\
& & Hol & Hum & Hol & Hum & Hol & Hum & Hol & Hum & Hol \\
\hline$+3 \mathrm{~K}$ & 53.24 & 61.25 & 30.6 & 32.29 & 45.11 & 39.86 & 97.89 & 131.83 & -7.32 & -7.12 \\
$+6 \mathrm{~K}$ & 76.7 & 91.51 & 48.45 & 51.30 & 50.22 & 47.60 & 137.82 & 197.97 & -12.84 & -12.61 \\
$+9 \mathrm{~K}$ & 87.61 & 116.35 & 65.42 & 66.75 & 51.76 & 48.87 & 147.21 & 255.58 & -14.60 & -14.32 \\
\hline
\end{tabular}
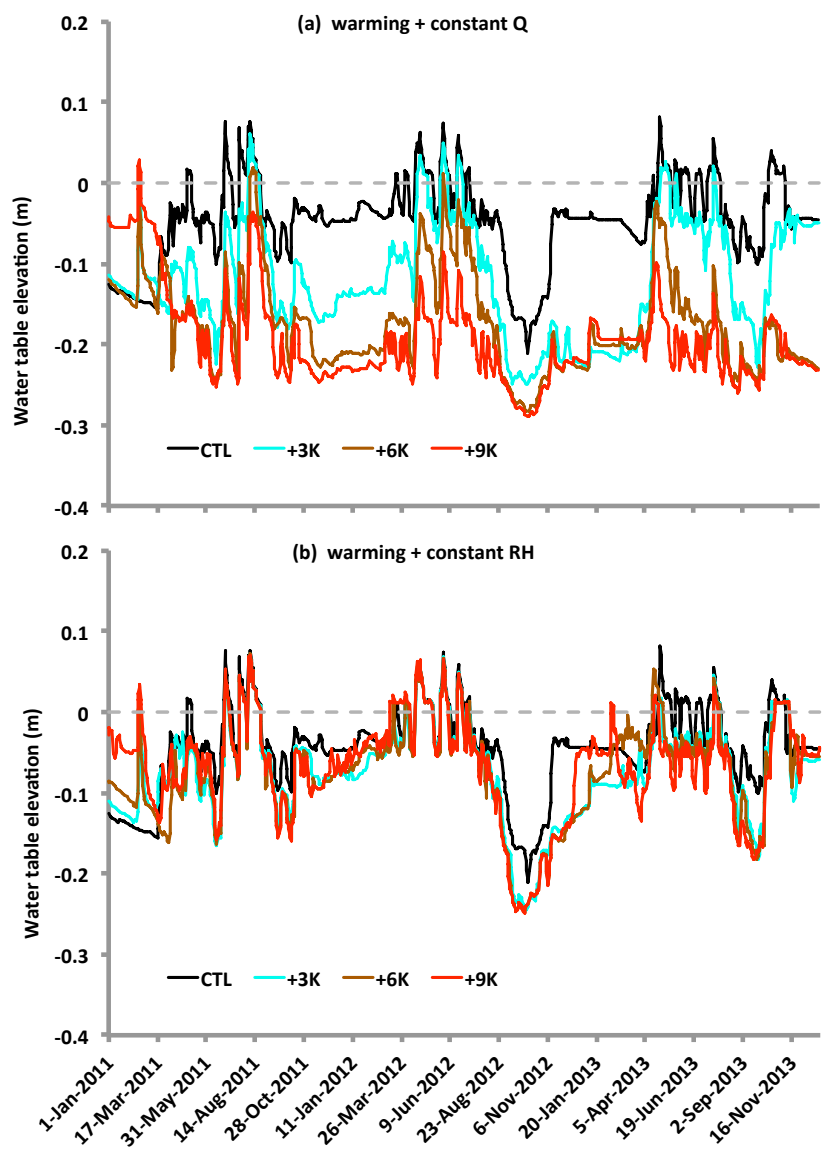

Figure 5. The simulated water table levels for years 2011-2013 for control (ambient) and warming scenarios $(+3,+6$ and $+9 \mathrm{~K}$ above ambient) based on two humidity conditions: (a) the same specific humidity for all four simulations (constant $Q$ ); and (b) the same relative humidity for all four simulations (constant $\mathrm{RH}$ ). Zero line indicates the surface of the hollow.

tion are adequate to evaporate most of the canopy intercepted precipitation even in the control simulation (Fig. 7, middle row). Evaporation from the bog surface $\left(E_{\mathrm{s}}\right)$ in these simulations is increased under the warming treatments throughout the year, with the largest increases in late winter and spring (Fig. 7, bottom row). At the highest levels of warming, simulated $E_{\mathrm{S}}$ is sometimes reduced compared to moderate warming in the late summer, due to reduced hydraulic conductivity
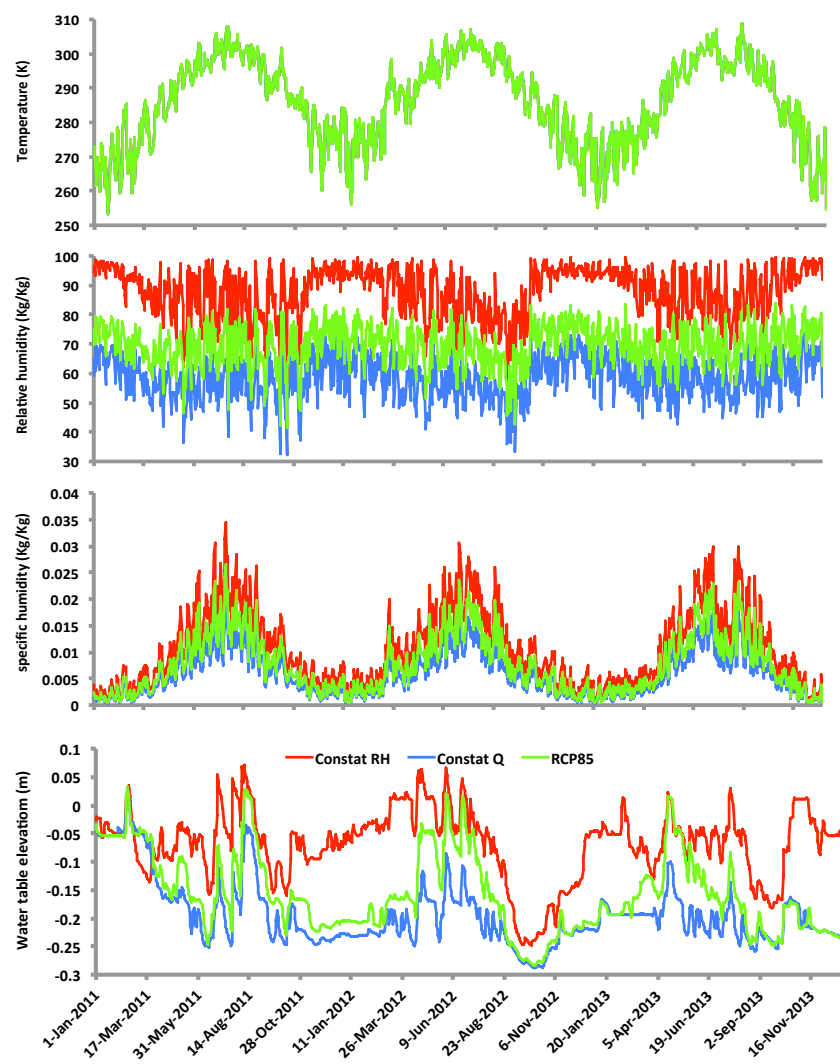

Figure 6. The evolution of temperature, relative humidity $(\mathrm{RH})$, specific humidity $(Q)$, and water table levels for warming $(+9 \mathrm{~K})$ scenarios with three different humidity conditions: red lines designate constant $\mathrm{RH}$; blue lines designate constant $Q$; green lines are for increasing $Q 30 \%$ and decreasing $\mathrm{RH} 14 \%$ (RCP8.5 scenario) for years 2011-2013.

for the dried upper layers of the soil. While observations of ET are not available for the S1-Bog site, a 21-year record of ET based on water budget observations at the nearby S2Bog provides a valuable basis for evaluation of our simulation results. Comparing the predicted and observed relationship of interannual ET to air temperature for a pre-warming simulation, we find that the simulated and observed slopes are nearly identical for the period 1979-1999, although the mean ET predicted at the S1-bog is about $15 \%$ lower than the mean observed at the S2-Bog (Fig. 8). Examining the 

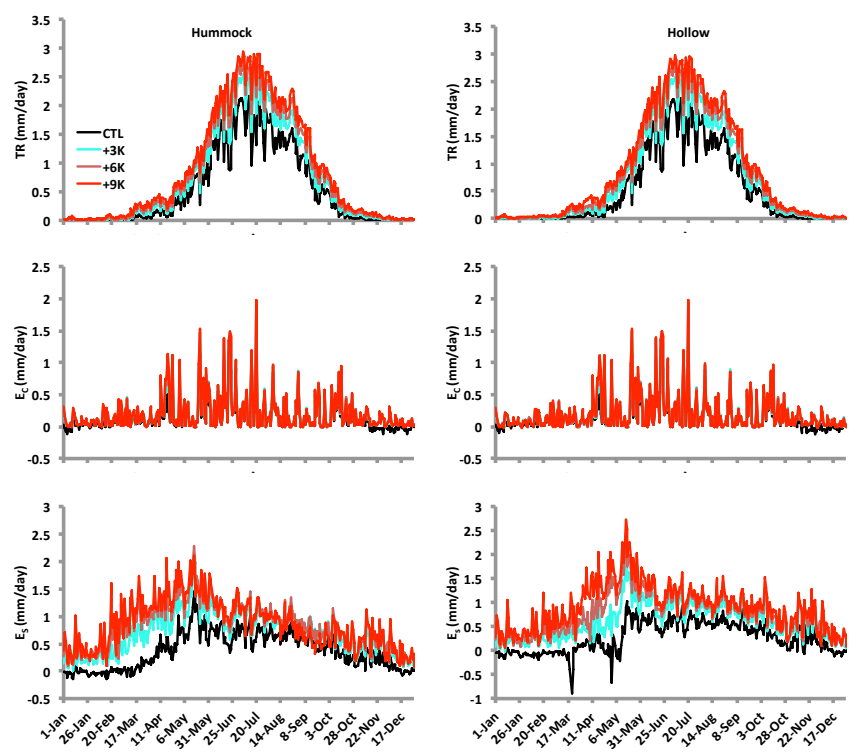

Figure 7. Seasonal dynamics (averaged over the 2011-2013 period) of three components of evapotranspiration, for control and 3 warming scenarios under the constant $Q$ assumption for humidity. TR, $E_{\mathrm{c}}$ and $E_{\mathrm{S}}$ are canopy transpiration, canopy evaporation and soil evaporation, respectively.

same relationship for a 14-year record of simulated warming at multiple warming levels, we find that the slope of the interannual relationship is consistent across the warming treatments and similar to the control period, although the strength of the interannual relationship weakens with higher levels of warming. Taken together, the control and warming experiments define a broad and approximately linear relationship between ET and $T$ with a slope that does not depart dramatically from the observed or modeled interannual relationships (Fig. 8). The current model does not consider Sphagnum physiology, which may help to explain the underestimation of ET since Sphagnum lack stomata while the model includes stomatal regulation. The S2-bog estimates of ET also include some contribution from upland vegetation, which could further contribute to bias in the model-data comparison. The model predicted summertime (June-August) ET rate is $2.4 \mathrm{~mm} \mathrm{~d}^{-1}$, well within the range of values reported from other peatlands in the northern latitudes (Moore et al., 1994; Lafleur et al., 1997; Wu et al., 2010).

\subsection{Influence of warming on simulated snow dynamics and soil temperature}

The S1-Bog (and surrounding region) is subject to snowpack accumulation, with a persistent snowpack commonly observed for the period November to April. Our control simulation reproduces this observed behavior (results not shown). Since snow is a good thermal insulator (e.g. Ge and Gong, 2010), and since a thick snowpack occurs during the coldest part of the year, the observed average soil temperature in the

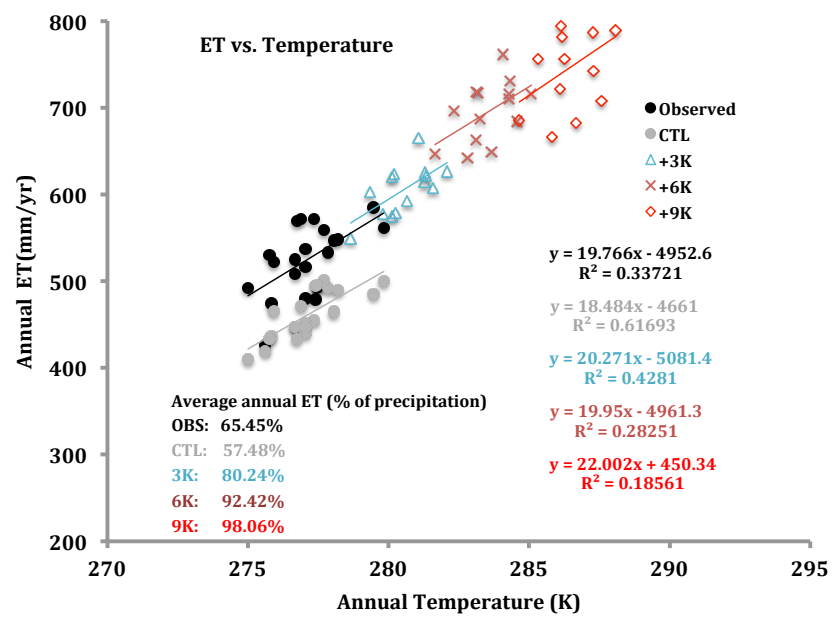

Figure 8. Annual total ET vs. annual mean air temperature. Observed values from the period 1979-1999 at the S2-Bog. Model values for pre-treatment control simulation using weather data for the period 1979-1999, and for three levels of imposed warming $(+3$, +6 and +9 K) based on weather data for the period 2000-2013. Regression lines are shown for interannual variation within each of these five categories.

bog is warmer than average air temperature, a pattern also reproduced by our control simulation.

In our warming simulations, higher air temperatures lead to a reduced snowfall amount (some precipitation that falls as snow in the control simulation falls as rain in the $+9 \mathrm{~K}$ warming simulation) and increased snow melt, both of which contribute to a reduced snowpack depth, with the effect concentrated during the period of typical highest snowpack accumulation in the late winter and spring (Fig. 9). The simulated influence on near-surface soil temperature of this modification of snowpack is dramatic, with very little difference between control and $+9 \mathrm{~K}$ treatment for the period JanuaryFebruary, warming effects increasing to a maximum over the period March-April, then declining to an intermediate level of warming which persists through the summer and into fall (Fig. 9). Reduced insulating effect of the thinner and more intermittent snowpack in the $+9 \mathrm{~K}$ simulation allows more cooling of the soil during very cold periods, negating the effect of increased air temperature. The influence of warming on deeper soil temperature (shown in Fig. 9 for a layer averaging $3.0 \mathrm{~m}$ deep) is much more consistent through the seasons: it is this deep soil temperature offset which sets the thermal baseline toward which shallower soil layers are drawn in the snow-free season, resulting in summer and fall near-surface soil temperatures that are less than the imposed warming of air temperature. The loss of insulation also results in more variability and more extremes in soil temperature. 


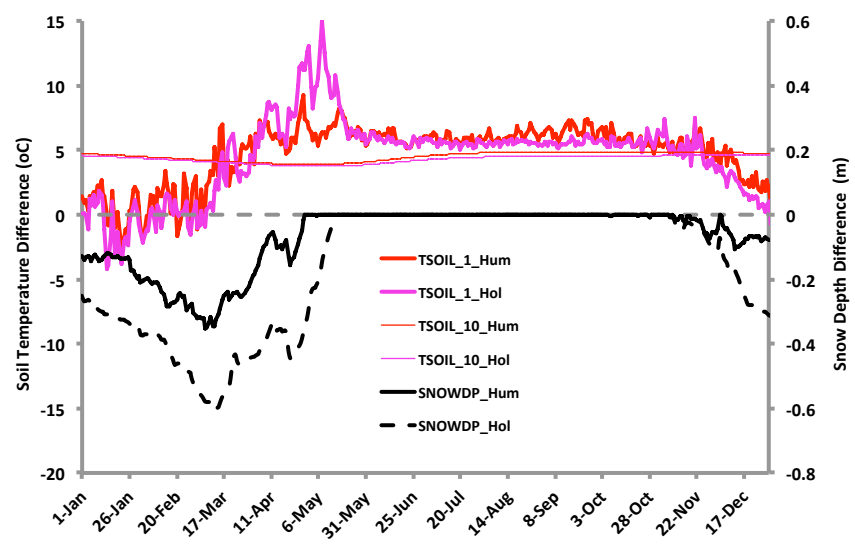

Figure 9. Differences (9 K-control) in soil temperature for first (TSOIL_1) and tenth (TSOIL_10) soil layers as predicted by CLM_SPRUCE under constant $Q$ assumptions for humidity. Also shown (right $x$ axis) is the difference in snowdepth (SNOWDP) over the hummock (Hum) and hollow (Hol) for the same pair of experiments. Model results are shown as the average seasonal cycle over the 2011 to 2013 period.

\section{Discussion}

The current study moves us closer to our long-term goal by improving the prediction of peatland water table depth in CLM, and by advancing the state of peatland ecosystem modeling within land surface models by introducing a formulation for the prediction of bog water table depth that does not depend on an externally forced regional water table. Our laterally coupled two-column hydrology scheme is a first-order approximation of the real bog's undulating hummock-hollow microtopography, and provides a basis for evaluating differences in vegetation distribution or function and differences in sub-surface biogeochemical processes as they exist pretreatment and as they may evolve under experimental manipulation.

Simulations presented here suggest that the hydrologic cycle within the S1-bog will respond to increased air temperature under the planned warming experiment and expected under projected climate change. Specifically, water table levels are expected to drop with increased air temperature as a result of increased evapotranspiration. However, the predicted reduction in water table level depends strongly on the level of warming and on the details of humidity modification. The warming influence on water table depth is expected to be larger for the anticipated experimental manipulation (close to constant $Q$ ) than would be the case if the experimental manipulation included injection of water vapor with heating of near-surface air (maintaining constant $\mathrm{RH}$ ).

The predicted influence of warming on ET under an assumption of constant specific humidity is quite dramatic at the higher warming levels, producing a significant drop in the simulated water table. Our evaluation of predicted ET and its sensitivity to air temperature indicates that the model produces a very realistic response of ET to temperature variation on interannual to decadal timescales. While we do not yet have any observations from the experimental warming treatments, we are able to show that the simulated response under those warming treatments follows an approximately linear extension of the response in the control period. Based on these preliminary evaluations, we do not have any particular reason to suspect that the simulated response of ET to warming is departing in an unrealistic way from the behavior of the real system. It is remarkable to note that at the highest warming levels nearly all of the annual precipitation is being evaporated, with only a few percent leaving as runoff. This suggests a fundamental shift in the character of the bog under levels of warming approximating "business-asusual" climate change scenarios. Perched water tables would likely decline under long-term exposure to these environmental conditions, if our model predictions are correct. Evaluations against observations at other bog sites, in particular for sites instrumented for eddy covariance estimates of ET, will be an important next step in our model evaluation efforts.

The interactions of air warming with snowpack and soil temperature simulated by CLM_SPRUCE raise some interesting challenges for the eventual interpretation of results from the SPRUCE warming experiment. Based on results presented here, we expect soil warming to be less than nearsurface air warming in systems with consistent over-winter snowpack, under a scenario of radiatively forced climate change. Since the experimental protocol for warming at the SPRUCE field site includes active below-ground heating elements and the maintenance of differential set points for below-ground temperature that match the air-warming differentials, the differences between soil warming and nearsurface air warming expected in nature will be attenuated in the experimental plots. Our modeling results suggest that extra energy will be added by the belowground control system to offset the effect of reduced thermal insulation due to smaller and shorter duration snowpack. This energy source belowground could drive additional interactions with snowpack and other aspects of hydrologic cycle in the heated plots.

In addition to simulations aimed at improved understanding of bog response to experimental manipulations at the plot-scale, we are also pursuing model implementations at larger spatial scales. By extending our simulation framework to include the entire bog domain, we will be able to evaluate large-scale hydrology against streamflow measurements from S1 and nearby bogs. We are already exploring the use of high-resolution gridded domains with explicit vertical and lateral flows as a foundation for more highly parameterized simulations that could allow us to estimate water, energy, and greenhouse gas fluxes for large landscapes in which peatland bogs are an important component. High-resolution elevation and remote-sensing information could be incorporated into these simulations to derive model parameters asso- 
ciated with microtopography, surface runoff and subsurface drainage such as lagg elevation. Since the CLM framework is already well suited to simulations in the upland regions of these domains, our current progress on simulating bog hydrology places this large-scale simulation goal within reach.

The success demonstrated here with a two-column parameterization of vertical and lateral hydrologic connectivity in a landscape characterized by small-scale topographic variation suggests that similar approaches may be useful in simulations of other similar landscapes. For example, our team is actively exploring multi-scale simulation approaches for representing geophysical, hydrological, biogeochemical, and botanical dynamics in Arctic polygonal tundra underlain by permafrost (e.g. Painter et al., 2013). With a modest increase in complexity we expect to be able to represent water table dynamics over regions of hundreds of $\mathrm{m}^{2}$ by tracking the vertical and lateral connectivity of a small number of columns representing, for example, polygon edges and centers. Parameterization for such coarse representations is being developed through very fine-scale process-resolving thermalhydrology simulation (e.g. Painter and Karra, 2014).

Simulating hydrological dynamics for microtopography of hummocks and hollows in the raised-dome bog environment is a necessary step toward more complete process representation that connects hydrology with vegetation dynamics, soil biogeochemistry, and estimation of greenhouse gas fluxes under changing climate conditions. Our initial efforts have focused on improvements in the modeling of peatland hydrology, but our ultimate goal is to integrate new modeling tools with observed ecosystem characteristics and results from experimental manipulations to understand the interactions of climate, hydrology, vegetation physiology, and biogeochemical cycling in these carbon-rich systems. Warming temperatures and shifting precipitation patterns have the potential to alter all aspects of these interactions, including the possibility of shifting peatland systems from net sinks to net sources of carbon (Limpens et al., 2008; Ise et al., 2008).

It has been suggested that the Sphagnum layer contributes significantly to total ecosystem $\mathrm{CO}_{2}$ flux (Oechel and Van Cleve, 1986), and thus plays an important role in the functioning of peatland ecosystem. Our current model work does not include a moss plant functional type and instead uses $\mathrm{C}_{3}$ grass as a proxy, which introduces potential biases. Mosses lack stomata, and the conductance to $\mathrm{CO}_{2}$ diffusion is controlled by a passively variable water layer (Silvola, 1990; Williams and Flanagan, 1996). Work is underway to introduce a new moss plant functional type in CLM_SPRUCE, and we will use observations being gathered from the S1Bog to parameterize the influence of water content on Sphagnum photosynthesis, and to better understand the influence of moss on hydrological and biogeochemical conditions in peatland bogs. Previous efforts at synthesizing and modeling moss physiology and physical properties are informing our progress in this area (St-Hilaire et al., 2010; Turetsky et al., 2012).

\section{Conclusions}

In this study, the CLM model (Oleson et al., 2013) was modified to explicitly simulate hydrological dynamics for the microtopography of hummocks and hollows in a raised bog environment (CLM_SPRUCE). The model was evaluated against half-hourly measurements of daily water table levels for 3 years. CLM_SPRUCE captures annual mean and seasonal dynamics in water table levels reasonably well, and eliminates deep water table and exaggerated seasonal dynamics biases associated with the default version of CLM4.5. The model reproduces the relationship between interannual ET and air temperature as observed at a nearby site. We used the new model CLM_SPRUCE to investigate the hydrological responses to different warming and humidity scenarios. Based on those simulations, we predict a deepening of the bog water table for the highest warming treatment $(+9 \mathrm{~K})$ planned in the SPRUCE experiment, greatly reducing the occurrence of standing water in the hollows. We estimate that the observed relationship between ET and air temperature will hold under conditions of experimental warming at levels out to $+9 \mathrm{~K}$. We also predict a strong interaction between the air heating treatment and the thickness and duration of snowpack, with consequences for subsurface temperatures that depend on snowfall amounts and mean winter temperature. These modeling results have helped raise awareness of the influence of operational decisions regarding over-winter heating of the sub-surface in the experimental design.

Acknowledgements. This material is based upon work supported by the US Department of Energy, Office of Science, Office of Biological and Environmental Research. Oak Ridge National Laboratory is managed by UT-Battelle, LLC for the US Department of Energy under Contract No. DE-AC05-00OR22725. The long-term research program at the MEF is funded by the Northern Research Station of the USDA Forest Service

Disclaimer. This manuscript has been authored by UT-Battelle, LLC, under Contract No. DE-AC05-00OR22725 with the US Department of Energy. The United States Government retains and the publisher, by accepting the article for publication, acknowledges that the United States Government retains a non-exclusive, paid-up, irrevocable, world-wide license to publish or reproduce the published form of this manuscript, or allow others to do so, for United States Government purposes.

Edited by: M. Williams

\section{References}

Andrus, R., Wagner, D. J., and Titus, J. E.: Vertical distribution of Sphagnum mosses along hummock-hollow gradient, Can. J. Botany, 61, 3128-3139, 1983.

Bohn, T. J., Podest, E., Schroeder, R., Pinto, N., McDonald, K. C., Glagolev, M., Filippov, I., Maksyutov, S., Heimann, M., 
Chen, X., and Lettenmaier, D. P.: Modeling the large-scale effects of surface moisture heterogeneity on wetland carbon fluxes in the West Siberian Lowland, Biogeosciences, 10, 6559-6576, doi:10.5194/bg-10-6559-2013, 2013.

Bond-Lamberty, B., Gower, S. T., and Ahl, D. E.: Improved simulation of poorly drained forests using Biome - BGC, Tree Physiol., 27, 703-715, 2007.

Bridgham, S. D., Megonigal, J. P., Keller, J. K., Bliss, N. B., and Trettin, C.: The carbon balance of North American wetlands, Wetlands, 26, 889-916, 2006.

Brooks, K. N., Verma, S. B., Kim, J., and Verry, E. S.: Scaling up evapotranspiration estimates from process studies to watersheds, in: Peatland biogeochemistry and watershed hydrology at the Marcell Experimental Forest, edited by: Kolka, R. K. Sebestyen, S. D., Verry, E. S., and Brooks, K. N., CRC Press, New York, 177-192, 2011.

Chapin, F. S., Van Cleve, K., and Chapin, M. C.: Soil temperature and nutrient cycling in the tussock growth form of Eriophorum vaginatum, J. Ecol., 67, 169-189, 1979.

Chen, J. M., Chen, X., Ju, W., and Geng, X.: Distributed hydrological model for mapping evapotranspiration using remote sensing inputs, J. Hydrol., 305, 15-39, doi:10.1016/j.jhydrol.2004.08.029, 2005.

Chen, X., Chen, J. M., An, S., and Ju, W.: Effects of topography on simulated net primary productivity at landscape scale, J. Environ. Manage., 85, 585-596, doi:10.1016/j.jenvman.2006.04.026, 2007

Couwenberg, J., and Joosten, H.: Self-organization in raised bog patterning: the origin of microtope zonation and mesotope diversity, J. Ecol., 93, 1238-1248, 2005.

Damman, A. W. H.: Distribution and movement of elements in ombrotrophic peat bogs, Oikos, 30, 480-495, 1978.

Dimitrov, D. D., Grant, R. F., Lafleur, P. M., and Humphreys, E. R.: Modeling the effects of hydrology on gross primary productivity and net ecosystem productivity at Mer Bleue bog, J. Geophys. Res., 116, G04010, doi:10.1029/2010JG001586, 2011.

Dise, N., Shurpali, N. J., Weishampel, P., Verma, S. B., Verry, E. S., Gorham, E., Crill, P. M., Harriss, R. C., Kelley, C. A., Yavitt, J. B., Smemo, K. A., Kolka, R. K., Smith, K., Kim, J., Clement, R. J., Arkebauer, T. J., Bartlett, K. B., Billesbach, D. P., Bridgham, S. D., Elling, A. E., Flebbe, P. A., King, J. Y., Martens, C. S., Sebacher, D. I., Williams, C. J., and Wieder, R. K.: Carbon emissions from peatlands, in Peatland biogeochemistry and watershed hydrology at the Marcell Experimental Forest, edited by: Kolka, R. K., Sebestyen, S. D., Verry, E. S., and Brooks, K. N, CRC Press, New York, 297-347, 2011.

Eppinga, M. B., de Ruiter, P. C., Wassen, M. J., and Rietkerk, M.: Nutrients and hydrology indicate the driving mechanisms of peatland surface patterning, Am. Nat., 173, 803-818, 2009.

Frolking, S., Roulet, N. T., Moore, T. R., Lafleur, P. M., Bubier, J. L., and Crill, P. M.: Modelling the seasonal to annual carbon balance of Mer Bleue bog, Ontario, Canada, Global Biogeochem. Cy., 16, 1030, doi:10.1029/2001GB001457, 2002.

Frolking, S., Roulet, N. T., Tuittila, E., Bubier, J. L., Quillet, A., Talbot, J., and Richard, P. J. H.: A new model of Holocene peatland net primary production, decomposition, water balance, and peat accumulation, Earth Syst. Dynam., 1, 1-21, doi:10.5194/esd-11-2010, 2010.
Ge, Y. and Gong, G.: Land surface insulation response to snow depth variability, J. Geophys. Res., 115, D08107, doi:10.1029/2009JD012798, 2010.

Gorham, E.: Northern peatlands: Role in the carbon cycle and probable responses to climatic warming, Ecol. Appl., 1, 182-195, 1991.

Grant, R. F., Desai, A. R., and Sulman, B. N.: Modelling contrasting responses of wetland productivity to changes in water table depth, Biogeosciences, 9, 4215-4231, doi:10.5194/bg-9-42152012, 2012.

Hanson, P. J., Kenneth, W. C., Wullschleger, S. D., Riggs, J. S., Thomas, W. K., Todd, D. E., and Warren, J. M.: A method for experimental heating of intact soil profiles for application to climate change experiments, Glob. Change Biol., 17, 1083-1096, 2011.

Hilbert, D. W, Roulet, N., and Moore, T. R.: Modelling and analysis of peatlands as dynamical systems, J. Ecol., 88, 230-242, 2000.

Idso, S. B.: A Set of Equations for Full Spectrum and 8- to $14 \mu \mathrm{m}$ and 10.5- to $12.5 \mu \mathrm{m}$ Thermal-Radiation from Cloudless Skies, Water Resour. Res., 17, 295-304, 1981.

Ise, T., Dunn, A. L., Wofsy, S. C., and Moorcroft, P. R.: High sensitivity of peat decomposition to climate change through watertable feedback, Nat. Geosci., 1, 763-766, 2008.

Johnson, L. C. and Damman, A. W. H.: Species-controlled Sphagnum decay on a south Swedish raised bog, Oikos, 61, 234-242, 1991.

Ju, W., Chen, J. M., Black, T. A., Barr, A. G., McCaughey, H., and Roulet, N. T.: Hydrological effects on carbon cycles of Canada's forests and wetlands, Tellus, Ser. B, 58, 16-30, doi:10.1111/j.1600-0889.2005.00168.x, 2006.

Kadlec, R. H. and Knight, R. L.: Treatment Wetlands, second Edn., CRC Press, Boca Raton, Florida, 21-57, 2009.

Kanamitsu, M., Ebisuzaki, W., Woollen, J., Yang, S., Hnilo, J. J., Fiorino, M., and Potter, G. L.: NCEP-DOE AMIP-II Reanalysis (R-2), B. Am. Meteorol. Soc., 83, 1631-1643, 2002.

Kazezyılmaz-Alhan, C. M., Medina Jr., M. A., and Richardson, C. J.: A wetland hydrology and water quality model incorporating surface water/groundwater interactions, Water Resour. Res., 43, W04434, doi:10.1029/2006WR005003, 2007.

Koven, C. D., Riley, W. J., Subin, Z. M., Tang, J. Y., Torn, M. S., Collins, W. D., Bonan, G. B., Lawrence, D. M., and Swenson, S. C.: The effect of vertically resolved soil biogeochemistry and alternate soil $\mathrm{C}$ and $\mathrm{N}$ models on C dynamics of CLM4, Biogeosciences, 10, 7109-7131, doi:10.5194/bg-10-7109-2013, 2013.

Lafleur, P. M., McCaughey, J. H., Joiner, D. W., Bartlett, P. A., and Jelinski, D. E.: Seasonal trends in energy, water, and carbon dioxide fluxes at a northern boreal wetland, J. Geophys. Res., 102, 29009-29020, doi:10.1029/96JD03326, 1997.

Lafleur, P. M., Roulet, N. T., Bubier, J. L., Frolking, S., and Moore, T.: Interannual variability in the peatland-atmosphere carbon dioxide exchange at an ombrotrophic bog, Global Biogeochem. Cy., 17, 1036, doi:10.1029/2002GB001983, 2003.

Lawrence, D. M. and Slater, A. G.: Incorporating organic soil into a global climate model, Clim. Dynam., 30, 145-160, doi:10.1007/s00382-007-0278-1, 2007.

Li, H., Huang, M., Wigmosta, M. S., Ke, Y., Coleman, A. M., Leung, L. R., Wang, A., and Ricciuto, D. M.: Evaluating runoff simulations from the community Land Model 4.0 using observa- 
tions from flux towers and a mountainous watershed, J. Geophys. Res., 116, D24120. doi:10.1029/2011JD016276, 2011.

Limpens, J., Berendse, F., Blodau, C., Canadell, J. G., Freeman, C., Holden, J., Roulet, N., Rydin, H., and Schaepman-Strub, G.: Peatlands and the carbon cycle: from local processes to global implications - a synthesis, Biogeosciences, 5, 1475-1491, doi:10.5194/bg-5-1475-2008, 2008.

Lindholm, T. and Markkula, I.: Moisture conditions in hummocks and hollows in virgin and drained sites on the raised bog Laaviosuo, Southern Finland, Ann. Bot. Fenn., 21, 241-255, 1984.

MacDonald, S. E. and Yin, F.: Factors influencing size inequality in peatland black spruce and tamarack evidence from post drainage release growth, J. Ecol., 87, 404-412, 1999.

Mezbahuddin, M., Grant, R. F., and Hirano, T.: Modelling effects of seasonal variation in water table depth on ecosystem $\mathrm{CO}_{2}$ exchange of a tropical peatland, Biogeosciences, 11, 577-599, doi:10.5194/bg-11-577-2014, 2014.

Moore, J. K., Lindsay, K., Doney, S. C., Long, M. C., and Misumi, K.: Marine Ecosystem Dynamics and Biogeochemical Cycling in the Community Earth System Model [CESM1(BGC)]: Comparison of the 1990s with the 2090s under the RCP4.5 and RCP8.5 Scenarios, J. Climate, 26, 9291-9312, 2013.

Moore, K. E., Fitzjarrald, D. R., Wofsy, S. C., Daube, B. C., Munger, J. W., Bakwin, P. S., and Crill, P.: A season of heat, water vapor, total hydrocarbon, and ozone fluxes at a subarctic fen, J. Geophys. Res., 99, 1937-1952, doi:10.1029/93JD01442, 1994.

Moore, T. R.: Growth and net production of Sphagnum at five fen sites, subarctic eastern Canada, Can. J. Bot. 67, 1203-1207, 1989.

Morris, P. J., Baird, A. J., and Belyea, L. R.: The role of hydrological transience in peatland pattern formation, Earth Surface Dynamics, 1, 29-43, 2013.

Nichols, D. S.: Temperature of upland and peatland soils in a north central Minnesota forest, Canadian J. Soil Sci., 78, 493-509, 1998.

Nichols, D. S. and Verry, E. S.: Stream flow and ground water recharge from small forested watersheds in north central Minnesota, J. Hydrol., 245, 89-103, 2001.

Niu, G., Yang, Z., Dickinson, R. E., and Gulden, L. E.: A simple TOPMODEL-based runoff parameterization (SIMTOP) for use in global climate model, J. Geophys. Res., 110, D21106, doi:10.1029/2005JD006111, 2005.

Nungesser, M. K.: Modelling mircrotopography in boreal peatlands: hummocks and hollows, Ecol. Modell., 165, 175-207, 2003.

Oechel, W. C. and Van Cleve, K.: The role of bryophytes in nutrient cycling in the taiga, in Ecological Studies, Vol. 57, Forest Ecosystems in the Alaskan Taiga, edited by: Van Cleve, K., Chapin III, F. S., Flanagan, P. W., Viereck, L. A., and Dyrness, C. T., Springer-Verlag, New York, 121-137, 1986.

Oleson, K. W., Niu, G., Yang, Z., Lawrence, D. W., Thornton, P. E., Lawrence, P. J., Stöckli, R., Dickinson, R. E., Bonan, G. B., Levis, S., Dai, A., and Qian, T.: Improvements to the Community Land Model and their impact on the hydrological cycle, J. Geophys. Res., 113, G01021, doi:10.1029/2007JG000563, 2008.

Oleson, K. W., Lawrence, D. W., Bonan, G. B., Drewniak, B., Huang, M., Koven, C. D., Levis, S., Li, F., Riley, W. J., Subin, Z. M., Swenson, S. C., Thornton, P. E., Bozbiyik, A., Fisher, R., Heald, C. L., Kluzek, E., Lamarque, J., Lawrence, P. J., Leung, L.
R., Lipscomb, W., Muszala, S., Ricciuto, D. M., Sacks, W., Sun, Y., Tang, J., and Yang, Z.: Technical description of version 4.5 of the Community Land Model (CLM), NCAR/TN-503+STR, NCAR Technical Note, 2013.

Painter, S. L. and Karra, S.: Constitutive model for unfrozen water content in subfreezing unsaturated soils, Vadose Zone J., 13, 1-8, doi:10.2136/vzj2013.04.0071, 2014.

Painter, S. L., Moulton, J. D., and Wilson, C. J.: Modeling challenges for predicting hydrologic response to degrading permafrost, Hydrogeol. J., 21, 221-224, doi:10.1007/s10040-0120917-4, 2013.

Parsekian, A. D., Slater, L., Ntarlagiannis, D., Nolan, J., Sebestyen, S. D., Kolka, R. K., and Hanson, P. J.: Uncertainty in peat volume and soil carbon estimated using ground-penetrating radar and probing, Soil Sci. Soc. Am. J., 76, 1911-1918. doi:10.2136/sssaj2012.0040, 2012.

Richardson, M. C., Mitchell, C. P. J., Branfireun, B. A., and Kolka, R. K.: Analysis of airborne LiDAR surveys to quantify the characteristic morphologies of northern forested wetlands, J. Geophys. Res., 115, G03005, doi:10.1029/2009jg000972, 2010.

Riley, W. J., Subin, Z. M., Lawrence, D. M., Swenson, S. C., Torn, M. S., Meng, L., Mahowald, N. M., and Hess, P.: Barriers to predicting changes in global terrestrial methane fluxes: analyses using CLM4Me, a methane biogeochemistry model integrated in CESM, Biogeosciences, 8, 1925-1953, doi:10.5194/bg-8-19252011, 2011.

Robreck, B. J. M., Schouten, M. G. C., Limpens, J., Berendse, F., and Poorter, H.: Interactive effects of water table and precipitation on net $\mathrm{CO}_{2}$ assimilation of three co-occurring Sphagnum mosses differing in distribution above the water table, Glob. Change Biol., 15, 680-691, 2009.

Sebestyen, S. D., Dorrance, C., Olson, D. M., Verry, E. S., Kolka, R. K., Elling, A. E., and Kyllander, R.: Long-term monitoring sites and trends at the Marcell Experimental Forest, in Peatland biogeochemistry and watershed hydrology at the Marcell Experimental Forest, edited by: Kolka, R. K. Sebestyen, S. D., Verry, E. S., and Brooks, K. N., CRC Press, New York, 15-71, $2011 \mathrm{a}$.

Sebestyen, S. D., Verry, E. S., and Brooks, K. N.: Hydrological responses to forest cover changes on uplands and peatlands, in: Peatland biogeochemistry and watershed hydrology at the Marcell Experimental Forest, edited by: Kolka, R. K. Sebestyen, S. D., Verry, E. S., and Brooks, K. N., CRC Press, New York, 433458, $2011 \mathrm{~b}$.

Silvola, J.: Combined effects of varying water content and $\mathrm{CO}_{2}$ concentration on photosynthesis in Sphagnum fuscum, Holarctic Ecol., 13, 224-228, 1990.

Silvola, J., Alm, J., Ahlholm, U., Nykanen, H., and Martikainen, P. $\mathrm{J} .: \mathrm{CO}_{2}$ fluxes from peat in boreal mires under varying temperature and moisture conditions, J. Ecol., 84, 219-228, 1996.

Sonnentag, O., Chen, J. M., Roulet, N. T., Ju, W., and Govind, A.: Spatially explicit simulation of peatland hydrology and carbon dioxide exchange: Influence of mesoscale topography, J. Geophys. Res., 113, G02005, doi:10.1029/2007JG000605, 2008.

Swanson, D. K. and Grigal, D. F.: A simulation model of mire patterning, Oikos, 53, 309-314, 1988.

Swenson, S. C., Lawrence, D. M., and Lee, H.: Improved simulation of the terrestrial hydrological cycle in permafrost regions by the community Land Model, J. Adv. Model. Earth Syst., 4, M08002, doi:10.1029/2012MS000165, 2012. 
St-Hilaire, F., Wu, J., Roulet, N. T., Frolking, S., Lafleur, P. M., Humphreys, E. R., and Arora, V.: McGill wetland model: evaluation of a peatland carbon simulator developed for global assessments, Biogeosciences, 7, 3517-3530, doi:10.5194/bg-7-35172010, 2010.

Tarnocai, C.: The impact of climate change on Canadian Peatlands, Can. Water Resour. J., 34, 453-466, 2009.

Thomas, P. R. and Yao, X.: Stochastic Ranking for Constrained Evolutionary Optimization, IEEE T. Evolut. Comput., 4, 274 283, 2000

Turetsky, M. R., Bond-Lamberty, B., Euskirchen, E., Talbot, J., Frolking, S., McGuire, A. D., and Tuittila, E. S.: The resilience and functional role of moss in boreal and arctic ecosystems, New Phytol., 196, 49-67, doi:10.1111/j.14698137.2012.04254.x, 2012.

Verry, E. S.: Microtropography and water table fluctuation in a Sphagnum mire, In Proceedings of the 7th International Peat Congress, Dublin, Ireland, The Irish National Peat Committee/The International Peat Society, 11-31, 1984

Verry, E. S. and Jansenns, J.: Geology, vegetation, and hydrology of the S2 bog at the MEF: 12,000 years in northern Minnesota, in Peatland biogeochemistry and watershed hydrology at the Marcell Experimental Forest, edited by: Kolka, R. K., Sebestyen, S. D., Verry, E. S., Brooks, K. N., CRC Press, New York, 93-134, 2011.

Verry, E. S., Boelter, D. H., Päivänen, J., Nichols, D. S., Malterer, T. J., and Gafni, A.: Physical properties of organic soils, in Peatland biogeochemistry and watershed hydrology at the Marcell Experimental Forest, edited by: Kolka, R. K., Sebestyen, S. D., Verry, E. S., and Brooks, K. N., CRC Press, New York, 135-176, $2011 \mathrm{a}$.

Verry, E. S., Brooks, K. N., Nichols, D. S., Ferris, D. R., and Sebestyen, S. D.: Watershed hydrology, in: Peatland biogeochemistry and watershed hydrology at the Marcell Experimental Forest, edited by: Kolka, R. K., Sebestyen, S. D., Verry, E. S., Brooks, K. N., 193-212, CRC Press, New York, 2011 b.
Verry, E. S., Bay, R. R., and Boelter, D. H.: Establishing the Marcell Experimental Forest: Threads in time, in: Peatland biogeochemistry and watershed hydrology at the Marcell Experimental Forest, edited by: Kolka, R. K., Sebestyen, S. D., Verry, E. S., and Brooks, K. N., CRC Press, New York, 1-13, 2011c.

Waddington, J. M., Rotenberg, P. A., and Warren, F. J.: Peat $\mathrm{CO}_{2}$ production in a natural and cutover peatland: Implications for restoration, Biogeochemistry, 54, 115-130, 2001.

Wania, R., Ross, I., and Prentice, I. C.: Implementation and evaluation of a new methane model within a dynamic global vegetation model: LPJ-WHyMe v1.3.1, Geosci. Model Dev., 3, 565-584, doi:10.5194/gmd-3-565-2010, 2010.

Williams, T. G. and Flanagan, L. B.: Effect of changes in water content on photosynthesis, transpiration and discrimination against ${ }^{13} \mathrm{CO}_{2}$ and $\mathrm{C}^{18} \mathrm{O}^{16}$ in Pleurozium and Sphagnum, Oecologia, 108, 38-46, 1996.

Wu, J., Roulet, N. T., Sagerfors, J., and Nilsson, M. B.: Simulation of six years of carbon fluxes for a sedge-dominated oligotrophic minerogenic peatland in Northern Sweden using the McGill Wetland Model (MWM), J. Geophys. Res.-Biogeo., 118, 795-807, doi:10.1002/jgrg.20045, 2013.

Wu, J. B., Kutzbach, L., Jager, D., Wille, C., and Wilmking, M.: Evapotranspiration dynamics in a boreal peatland and its impact on the water and energy balance, J. Geophys. Res, 115, G04038, doi:10.1029/2009JG001075, 2010.

Zhang, Y., Li, C., Trettin, C. C., Li, H., and Sun, G.: An integrated model of soil, hydrology, and vegetation for carbon dynamics in wetland ecosystems, Global Biogeochem. Cy., 16, 1061, doi:10.1029/2001GB001838, 2002. 